A n n a Seredyń ska ORCID: 0000-0002-0483-6281

Akademia Ignatianum w Krakowie

\title{
Motywacje wolontariuszy hospicyjnych na poczq̨tku i w trakcie posługi
}

\author{
Initial Motivations of Hospice Volunteers and \\ During their Ministry
}

\begin{abstract}
ABSTRAKT
Wolontariat hospicyiny to bardzo specyficzny rodzaj wolontariatu, zwiqzany z opiekq nad chorymi i umierajqcymi w okresie terminalnym choroby. Przedmiotem artykułu sq motywacje wolontariuszy hospicyjnych. Chodzi tutaj zarówno o motywacje, jakimi się kierowali w momencie przyjścia do hospicjum, jak i te, które maja obecnie, po pewnym czasie posługiwania. Celem artykułu jest nie tylko ich opisanie i porównanie, ale również pokazanie jak wyglaqdaja one w zależności od wieku wolontariuszy, ich stażu oraz rodzaju pełnionej posługi. Dzięki tym badaniom można odkryć nie tylko same motywy podięcia pracy w wolontariacie hospicyjnym, ale również to, co powoduje, że ktoś jest w stanie w tej pracy dłużej wytrwać. Jest to pytanie ważne dla osób odpowiedzialnych za rekrutację nowych wolontariuszy.

W części teoretycznej artykułu zostały ukazane podstawowe poięcia zwiqzane $z$ wolontariatem hospicyjnym oraz motywacjami do jego podięcia. Część badawcza to analiza wyników badań własnych otrzymanych na drodze metody sondażowej. Owocem badań sq stwierdzenia dotyczqce motywacji towarzyszqcej wolontariuszom na poczq̨tku ich posługi, obecnie, oraz motywacji w zależności od wieku, stażu i rodzaju posługi badanych.
\end{abstract}

SLOWA KLUCZOWE

wolontariat hospicyiny, motywacja,

wolontariusz, wytrwanie w posłudze, altruizm

\section{KEYWORDS}

hospice volunteering, motivation, volunteer, perseverance in ministry, altruism

SPI Vol. 22, 2019/3

ISSN 2450-5358

e-ISSN 2450-5366

DOI: 10.12775/SPI.2019.3.007

Nadesłano: 4.05.2019

Zaakceptowano: 3.11.2019

Raporty z badań 


\section{ABSTRACT}

Hospice volunteering is a very specific type of volunteering connected with care for the sick and dying in the terminal period of the disease. The subject of the article are the motivations of hospice volunteers: the ones they had when they came to the hospice and those they have after a period of service. The aim is not only to describe and compare them, but also present their outlook depending on the age of volunteers, the length of their ministry and the type of ministry. Thanks to this research, motivations emerge as to why someone might choose to become a hospice volunteer, as well as what makes someone able to persevere in this service. This is an important question for those responsible for recruiting new volunteers.

In the theoretical part of the article, the basic notion connected with hospice volunteering and motivations to take it were shown. The research part is the analysis of results obtained through the survey method. The fruit of the research are statements regarding the motivation at the beginning of the ministry, currently, and differences in motivation depending on age, and the length and type of ministry of the respondents.

\section{Wprowadzenie}

Każdego kandydata, który przychodzi z pragnieniem wejścia w skład wolontariatu hospicyjnego, pyta się o jego motywy podjęcia wolontariatu. Większość ma konkretne powody, dla których chce podjąć taką posługę. Osoby, które nie mają skonkretyzowanych motywów swojego przyjścia do wolontariatu, z reguły odchodzą. $\mathrm{C}$, którzy zostają, mają możliwość zmiany swoich motywów. I wówczas pojawia się już nowa motywacja.

Paradygmatem, który stał się podstawą niniejszych badań, był funkcjonalizm strukturalny, w ramach którego można założyć pewną rolę pełnioną przez wolontariuszy w hospicjach (Babbie 2013). Rola ta jest związana z konkretnymi motywacjami tych osób. Przedmiotem niniejszego artykułu jest różnica pomiędzy motywacjami, z którymi wolontariusze przychodzą do hospicjum, a tymi, z powodu których tam zostają.

W części teoretycznej artykułu zostały opisane podstawowe pojęcia związane $\mathrm{z}$ wolontariatem, rzeczywistością hospicjum oraz motywacją. W następnej części zaprezentowano analizę wyników 
własnych badań sondażowych przeprowadzonych wśród wolontariuszy Hospicjum św. Łazarza w Krakowie.

\section{Znaczenie wolontariatu hospicyjnego}

Termin „hospicjum” pochodzi z języka łacińskiego (hospes) i oznacza gościnę, zajazd, dom gościnny, kwaterę (Weber 2009). Hospicjum jednak nie łączy się tylko z konkretnym miejscem. Hospicjum to ludzie udzielający umierającym „gościny serca”. Założycielką pierwszego hospicjum na świecie (Hospicjum św. Krzysztofa - rok 1967) była Cicely Saunders. Twierdziła, że „w centrum naukowych zainteresowań zespołu pracującego w hospicjum znajduje się walka z bólem"(Saunders 1980: 266). Praca hospicjum sytuuje się według Saunders w obrębie systemu opieki (care system), który powinien być uzupełnieniem cure system, czyli systemu uzdrawiania (Saunders 1980). W ramach opieki powinno się zapewnić choremu, na ile to możliwe, komfort fizyczny i psychiczny. Saunders uważała, że w ramach opieki hospicyjnej „mamy obowiązek walczyć o życie, nie zaś o przedłużenie umierania" (Saunders 1980: 271). Hospicjum to nie miejsce biernej eutanazji, ale starannego leczenia objawowego, paliatywnego. Hospicjum to też miejsce spotkania „dobrych ludzi, którzy zawsze znajdą czas na cierpliwe wysłuchanie drugiego, umieją usługiwać $\mathrm{z}$ wyczuciem, taktownie, $\mathrm{z}$ pełnym zaangażowaniem i zarazem spokojem"(Saunders 1980: 287).

Eugeniusz Dutkiewicz, założyciel hospicjum „Pallottinum” w Gdańsku, twierdził, że hospicyjna opieka duchowa to „przeprowadzenie umierającego ku progom wieczności”(Dutkiewicz 1997: 111). Według Eugeniusza Dutkiewicza, „hospicjum (...) chce takim wartościom jak godność osoby cierpiącej, jak służba, przywracać należne i właściwe miejsce w medycynie”(Dutkiewicz 1997: 115). Definiując rozumienie pojęcia hospicjum, Dutkiewicz stwierdził, że „podstawowym kluczem filozofii opieki hospicyjnej, aby była natchniona gościnnością serca, jest czas”(Dutkiewicz 1997: 119), a więc „zespół hospicyjny musi być grupa przyjaciól, którym przyświeca wspólne pojmowanie idei hospicyjnej, wspólny cel i orientacja"(Dutkiewicz 1997: 119).

Bardzo duże znaczenie w pracy hospicjum mają wolontariusze.Jadwiga Przewłocka w swoim raporcie podała definicję wolontariusza: 
Wolontariuszem jest osoba fizyczna, która ochotniczo i bez wynagrodzenia wykonuje świadczenia na rzecz organizacji pozarządowych, podmiotów kościelnych (wyznaniowych), spółdzielni socjalnych, a także organów administracji publicznej lub podległych im jednostek (Przewłocka 2010: 7).

Natomiast według Marty Gumkowskiej „wolontariat to bezpłatne, dobrowolne, świadome działanie na rzecz innych, wykraczające poza więzi rodzinno-koleżeńsko-przyjacielskie"(Gumkowska 2005: 3). Taką definicję również podaje Piotr Krakowiak za Biurem Obsługi Ruchu Inicjatyw Społecznych, pisząc, że wolontariat jest działaniem bezpłatnym, świadomym, dobrowolnym, na rzecz innych, wykraczającym poza więzi rodzinno-koleżeńsko-przyjacielskie (Krakowiak, Janowicz 2008). W świetle Ustawy o wolontariacie wolontariusz to osoba, „która ochotniczo i bez wynagrodzenia wykonuje świadczenia na zasadach określonych w ustawie" (Ustawa o dziatalności pożytku publicznego i wolontariacie 2003, art. 2).

Można więc na podstawie tych definicji stwierdzić, że wolontariat jest związany z wykonywaniem pracy ochotniczo i bez wynagrodzenia, dobrowolnie i świadomie. Jednak ważnym aspektem jest również fakt, że o wolontariacie można mówić w wypadku, kiedy te działania dotyczą osób spoza rodziny i przyjaciół.

Wolontariat hospicyjny związany z posługą chorym, umierającym i ich rodzinom jest bardzo specyficznym i trudnym rodzajem wolontariatu. Motywacja, która do niego skłania, często różni się od motywacji w innych rodzajach wolontariatu.

\section{Motywacja do podięcia wolontariatu, w tym wolontariatu hospicyinego}

Według psychologów, motywacja to

(...) z jednej strony dyspozycja do uruchamiania, podtrzymywania, ukierunkowywania danych form zachowań (...), a z drugiej strony aktualnie przebiegający proces aktywności ukierunkowanej na spełnienie bliżej lub mniej określonych celów, której towarzyszą rozmaite odczucia (emocje) i która angażuje różne inne formy życia psychicznego (np. myślenie, pamięć) (Gasiul 2002: 223). 
Jadwiga Przewłocka w raporcie dotyczącym wolontariatu i działań filantropijnych w Polsce podała następujące motywy skłaniające Polaków do podejmowania działań wolontariackich: przyjemność (43\%), oczekiwanie, że ktoś mi pomoże, jak ja jemu pomogę (32\%), wartości (29\%), kontakt z ludźmi i wykorzystanie czasu (23\%), zdobycie nowych umiejętności (21\%), naśladowanie znajomych (18\%), nieumiejętność odmowy (13\%), dług do spłacenia (4\%), zdobycie doświadczenia do przyszłej pracy (2\%) (Przewłocka 2010).

Badania te dotyczyły ogółu Polaków. Nieco inaczej kształtują się te motywy w przypadku młodzieży. Motywacje podejmowania wolontariatu zostały zbadane w grupie młodzieży szkolnej (Kapuścińska 2012). Badania te objęły 96 uczniów II i III klas szkoły średniej. $27,1 \%$ badanych podało jako motyw satysfakcję i przyjemność $\mathrm{z}$ takiej pracy. 21,9\% pisało, że pomaga, bo inni tak robią. $18,7 \%$ miało nadzieję na odwzajemnienie pomocy. $16,7 \%$ pisało o chęci poznania innych przy okazji wolontariatu. $11,5 \%$ podało, że sytuacja tego wymaga, a 4,1\% jako powód podało brak zajęcia oraz inne motywy. Jak widać, mniej tutaj osób podających jako przyczynę przyjemność z takiej pracy, natomiast dla wielu motywacją była chęć poznania poprzez wolontariat innych osób.

W innych badaniach, w grupie 81 wolontariuszy, 20,1\% uważało, że powinno się pomagać innym. 4,9\% miało nadzieję, że pomoc będzie w przyszłości odwzajemniona (Ożóg 2012). 21,9\% sprawiało to przyjemność, 4,9\% nie potrafiło odmawiać, 17\% chciało się czegoś nauczyć. 4,9\% badanych liczyło na wyjazdy z wybraną organizacją, 1,9\% pragnęło później tam pracować, 18,5\% chciało zrobić coś dobrego, 4,9\% czuło powołanie do niesienia pomocy innym, zaś 1,5\% miało inne motywy. Te badania dotyczyły również osób w różnym wieku, ale raczej młodych. Pojawił się motyw, który jest związany z organizacjami prowadzącymi wolontariat w różnych krajach, a więc związany z możliwością skorzystania $\mathrm{z}$ wolontariatu jako sposobu na poznawanie tych krajów. Te motywy widać również w badaniu 29 wolontariuszy pracujących w Chinach. Okazało się, że 14\% spośród badanych jako motyw podjęcia wolontariatu międzynarodowego podało chęć podróżowania, 72\% - chęć pomagania innym, 62\% - chęć zdobycia nowych doświadczeń, 45\% - rozwój osobowy, 21\% - zdobycie doświadczeń praktycznych, 3\% - ucieczkę od wymagań życia, zaś 3\% zrobienie sobie przerwy od codzienności (Jackson, Adarlo 2016). 
Motywacje wolontariuszy badane są na różne sposoby. Wśród wolontariuszy chińskich próbowano na przykład badać motywację przygotowanym przez badaczy na tę okoliczność kwestionariuszem (Wu, Li, Khoo 2016). Przebadano 362 osoby i odkryto 5 czynników motywujących: wewnętrzną motywację, zidentyfikowaną regulację, zewnętrzną regulację, wprowadzoną regulację oraz amotywację.

W wymienianych badaniach jako motyw podjęcia pracy w wolontariacie pojawiło się pragnienie zdobycia doświadczenia zawodowego (Bacter, Marc 2016; Goodman, Tredway 2016). Okazuje się również, że w świetle badań osoby zaangażowane w wolontariat charakteryzują się niższym poziomem wypalenia zawodowego oraz niższym poziomem stresu (Ramos, Gunter, Brauchli i in. 2016).

W 2013 roku przebadano na 67 mężczyznach i 226 kobietach związek pomiędzy identyfikowaniem się z motywacjami prospołecznymi i internalizacją norm społecznych (Winterich, Aquino, Mittal, Swartz 2013). U osób, które dobrze internalizują normy społeczne, ideały czy tzw. wysokie cele, występuje też w większym stopniu orientacja na innych i gotowość do podejmowania wolontariatu.

Badania narracyjne przeprowadzone na grupie 14 wolontariuszy krótkoterminowych działających w Stowarzyszeniu Nowa Szkocja-Gambia pokazały wpływ na tworzenie się silniejszego związku z pełnionym wolontariatem (Campbell, Warner 2016). Okazało się, że osoby, które bardziej angażowały się w relacje z ludnością miejscową, były później bardziej zaangażowane w pracę w wolontariacie.

Jak wykazały badania przeprowadzone na innych 5515 wolontariuszach, bardzo ważne znaczenie dla motywacji do pracy w wolontariacie ma strona organizacyjna wolontariatu oraz klimat istniejący w organizacjach non-profit (Van Schie, Gunter, Oostlander, Wehner 2015; Nencini, Romaidi, Maneghini 2016). Ten klimat jest swego rodzaju „mediatorem” pomiędzy wewnętrzną motywacją i satysfakcją.

Okazało się również, że w pozostaniu w wolontariacie bardzo duże znaczenie mają kompetencje społeczne osób zaangażowanych (Li, Wu, Kee 2016).

$\mathrm{W}$ badaniu przeprowadzonym w jednej z organizacji religijnych w Australii wykazano, że w motywach podjęcia wolontariatu bardzo ważną rolę pełni motywacja religijna (Erasmus, Morey 2016). Ma ona duże znaczenie dla satysfakcji z pomagania oraz z zachowań 
społecznych, co stwierdzono badając próbę złożoną z 107 osób, w tym 63 kobiet i 44 mężczyzn.

Bardzo specyficznym rodzajem wolontariatu jest zaangażowanie w badania naukowe. Jest ono również złożone pod względem motywacyjnym (Kwakye, Garner, Baldwin i in. 2016). Silną motywacją w takim zaangażowaniu jest motywacja finansowa. Jednak i w takim wolontariacie istnieją inne motywy, jak np. chęć pomocy naukowcom czy też chęć bycia częścią jakiegoś większego projektu.

W pracy wolontariusza motywacja egoistyczna walczy często z motywacją altruistyczną (Włodarczyk 2011). Samo podjęcie wolontariatu oczyszcza motywy egoistyczne i motywacja staje się coraz bardziej altruistyczna. Dlatego motywowanie do wykonywania zadań wolontariackich $z$ jednej strony odbywa się poprzez budzenie altruizmu, ale $z$ drugiej poprzez podawanie korzyści, którymi są: zdobycie doświadczenia zawodowego, nowych umiejętności, nawiązywanie kontaktów społecznych oraz uzyskiwanie korzyści indywidualnych i satysfakcji (Basińska, Nowak 2010).

Specyficznym rodzajem wolontariatu jest niewątpliwie pomoc osobom chorym i niepełnosprawnym. Wśród 10 badanych wywiadem narracyjnym wolontariuszy pracujących z głuchoniewidomymi pojawiły się następujące czynniki motywujące: chęć zaspokojenia własnych potrzeb dotyczących wartości, potrzeba zrozumienia świata, potrzeba zbudowania własnej hierarchii wartości, możliwość zdobycia doświadczenia zawodowego, potrzeba odnalezienia swojej grupy i dopasowania, chęć zrozumienia i poradzenia sobie ze swoimi problemami (Sobolewska-Popko 2012). Badanie motywacji do wolontariatu na olimpiadzie dla osób niepełnosprawnych zostało przeprowadzone na próbie 252 osób (Kumnig, Schnitzer, Beck i in. 2015). Badano ich cechy socjodemograficzne, zadowolenie $z$ życia i samopoczucie, jak również zadowolenie $z$ wykonywanych zadań. Okazało się, że zadowolenie z życia i dobre samopoczucie są dobrym predyktorem zaangażowania w wolontariat. Mirosław Górecki na podstawie badań przeprowadzonych wśród wolontariuszy hospicyjnych podzielił motywacje do podejmowania wolontariatu hospicyjnego na: altruistyczną (46,3\%), zadaniową (21,8\%), ideologiczną (14,8\%), afiliacyjną, czyli związaną z poszukiwaniem środowiska osób podobnie myślących (9,2\%) oraz egoistyczną (7,9\%) (Górecki 2000). W 2005 roku zostały przeprowadzone wywiady (10) w trzech hospicjach 
w Szwecji z wolontariuszami (Andersson, Ohlen 2005). Pokazały one, że motywacja do posługi wolontariackiej jest bardzo złożona. U badanych osób motywacja altruistyczna była nierozerwalnie związana $\mathrm{z}$ realizowaniem $\mathrm{w}$ ramach wolontariatu własnych interesów.

W 2008 roku zostały przeprowadzone badania 192 wolontariuszy dotyczące ich motywacji i satysfakcji z posługi (Finkelstein 2008). Większą satysfakcję z posługi doświadczają osoby, których motywacją na początku była chęć pomagania innym. Takie osoby dłużej pozostają w wolontariacie.

W badaniach dotyczących przekroju społecznego wolontariuszy hospicyjnych stwierdzono, że są to najczęściej osoby rasy białej, zamężni, w średnim wieku, zadowoleni finansowo, niepracujący, kobiety, wierzący i religijni (Starnes, Wymer 1999). Motywy do wolontariatu bywają zarówno altruistyczne, jak też osobiste, związane z sytuacją danej osoby.

W wolontariat hospicyjny angażuje się wiele osób starszych. Badanie motywacji wolontariuszy będących w różnym wieku wykazało, że osoby młodsze są bardziej nastawione w wolontariacie na budowanie nowych relacji (Omoto, Snyder, Martino 2000). Osoby zaś starsze są bardziej nastawione altruistycznie, na służenie innym.

Badanie 955 osób starszych w wolontariacie 50+ pokazało, że na zaangażowanie $\mathrm{w}$ wolontariat bardzo mocno wpływają indywidualne zasoby badanych związane $\mathrm{z}$ ich związkami osobowymi (Principi, Naegele, Di Rosa, Lamura 2016). Wolontariat wśród osób starszych, jak pokazały badania na próbie 277 wolontariuszy z organizacji Oshar Lifelong Learning w USA, jest sposobem wdrażania się do uczenia przez całe życie (Yamashita, Lopez, Soligo, Keene 2017).

Widząc jak ważne jest zadanie wolontariuszy w różnych organizacjach, osoby odpowiedzialne tworzą programy mające na celu wpływanie na motywacje młodych ludzi angażujących się w wolontariat (Chien 2017). Jednym z takich programów są specjalne szkolenia w naukach ścisłych organizowane na Tajwanie dla wolontariuszy. Badania na próbie 289 wolontariuszy wykazały znaczenie uczestnictwa w projekcie dla późniejszego zaangażowania się w wolontariat naukowy i satysfakcji jaka z takiej działalności wynika.

Budując motywację zarówno zewnętrzną, jak i wewnętrzną odpowiedzialni za wolontariuszy tworzą dla nich specjalne programy przygotowania (Stukas, Snyder, Clary 2016). 


\section{Procedura badawcza}

Badania własne zostały przeprowadzone w 2017 roku na grupie 46 wolontariuszy Hospicjum św. Łazarza w Krakowie. Przedmiotem badań były te motywacje podjęcia wolontariatu hospicyjnego, z którymi osoby przyszły do hospicjum oraz te, które w obecnym czasie podtrzymują ich trwanie w wolontariacie. Celem teoretycznym było odkrycie na ile motywacje potrafią się zmieniać. Cel praktyczny związany był ze zdobyciem wiedzy na temat tego, co sprawia, że wolontariusze często przez wiele lat kontynuują swoją posługę w wolontariacie. Problem główny postawiono w formie pytania: „Jaka jest różnica pomiędzy motywacjami, które skłoniły wolontariusza do podjęcia wolontariatu, a tymi, które powodują, że on w tym wolontariacie trwa? Jako problemy szczegółowe zostały postawione trzy pytania: (1) Jaka jest zależność pomiędzy motywacją wolontariuszy oraz ich wiekiem i długością trwania posługi? (2) Jaka jest zależność pomiędzy motywacją wolontariuszy a rodzajem zaangażowania w wolontariat? (3) Jaka jest różnica w motywacji wolontariusza na początku posługi i w chwili obecnej?

Zmiennymi w badaniach była motywacja wolontariuszy na początku posługi i obecnie, ich wiek, staż posługi w hospicjum oraz rodzaj zaangażowania w wolontariat. Wskaźnikami motywacji był wybór rodzaju motywacji $\mathrm{z}$ dwóch spisów: jednego związanego z początkiem posługi, zaś drugiego - związanego z chwilą obecną. Metodą badawczą był sondaż, techniką - ankieta, zaś narzędziem kwestionariusz opracowany przez autorkę. Kwestionariusz został opracowany na podstawie badań zastanych. Wyróżnia on różne rodzaje motywacji, które są podawane w literaturze oraz przez kandydatów podczas rozmów wstępnych prowadzonych przez autorkę od roku 2012 do 2018. Wśród różnych motywów podejmowania wolontariatu można tu wymienić: brak sprecyzowanych powodów podjęcia wolontariatu, samotność, pragnienie naprawienia swoich błędów popełnionych w opiece nad bliskimi, szukanie życzliwego środowiska, próbę radzenia sobie ze swoimi problemami, pójście za czyjąś radą w kwestii wyboru wolontariatu, kierowanie się wartościami wyższymi, pragnienie podzielenia się dobrem, które się samemu otrzymało od Boga, przyjemność z takiej pracy, oczekiwanie na pomoc ze strony innych $\mathrm{w}$ ramach wzajemności, pragnienie poznania innych 
ludzi, pragnienie zdobycia nowych umiejętności, naśladowanie znajomych, nieumiejętność odmowy przyjścia z pomocą, pragnienie spłacenia długu, pragnienie zyskania doświadczenia, pragnienie poczucia się docenionym, spotkanie z problemem choroby nowotworowej u najbliższych oraz inne motywy. Poza pytaniami dotyczącymi danych socjodemograficznych pojawiły się dwa inne pytania. Jedno dotyczyło zaznaczenia motywacji, z którą wolontariusz przyszedł do hospicjum. Drugie motywacji obecnej, tej, która mobilizuje go dzisiaj do posługiwania. Pierwsze pytanie dotyczyło więc retrospekcyjnego spojrzenia na własne motywy, zaś drugie uświadomienia sobie teraźniejszego ich stanu. Miało to znaczenie edukacyjne. Osoby badane miały bowiem możliwość dokonania pewnego rodzaju refleksji nad swoją posługą.

Próba badawcza została dobrana w sposób celowy spośród wolontariuszy posługujących w Hospicjum św. Łazarza w Krakowie. Stanowili ją wolontariusze, którzy uczestniczą w comiesięcznych spotkaniach wolontariatu. Zostali oni poinformowani o celu badań. Badania były anonimowe. Wolontariusze nie musieli w nich uczestniczyć. Ankietę przeprowadziła z wolontariuszami Bożena Wąż, koordynator zespołu wolontariatu. Zostało przebadanych 46 wolontariuszy. Ich średnia wieku wynosi 57 lat $\left(\mathrm{s}^{1}=13,93\right)$. Średnia długość posługiwania w hospicjum wynosi 6 lat $(s=7,23)$. W grupie znajdowało się 37 kobiet i 9 mężczyzn.

Większość badanych ukończyła kurs, który odbył się w roku 2017. Jednak po podzieleniu na dwie grupy okazało się, że przed rokiem 2012 w kursie brało udział 14 wolontariuszy spośród badanych, a po tym roku 32 osoby. Rok 2012 był ważny dla Hospicjum św. Łazarza, gdyż w tym roku odeszła z posługi koordynator, która przez 20 lat prowadziła zespół. Zespół wolontariatu był bardzo z nią zżyty, co widać choćby w tym, że stosunkowo wiele osób przygotowanych przez nią (30\%) wytrwało do tej pory w wolontariacie.

W hospicjum stacjonarnym posługuje 40 osób spośród badanych. Sześć osób pracuje w hospicjum domowym. W Klubie doktora Deszcza dla osób osieroconych jest zaangażowana jedna osoba spośród badanych. W grupie modlitewnej jest zaangażowana jedna osoba, zaś inna osoba spośród badanych jest zaangażowana w wolontariat

${ }^{1} \mathrm{~S}$ - odchylenie standardowe 
administracyjny. Niektórzy spośród badanych angażują się w kilka rodzajów posługi.

\section{Analiza wyników badań}

Wyniki badań zostały opracowane za pomocą testów statystycznych. Ponieważ motywacja jest zmienną dwuwartościową, dlatego zastosowano testy nieparametryczne: test rho Spearmana oraz test kolejności par Wilcoxona liczący różnice zmiennej w dwóch grupach zależnych. Omówienie poszczególnych problemów badawczych zakończono dyskusją wyników.

\section{Motywacja badanych na poczq̨tku posługi i obecnie}

Badani mieli za zadanie zaznaczyć w kwestionariuszu motywy, z którymi przyszli do posługi w hospicjum na początku oraz te, które dzisiaj są ich motywami pozostawania w wolontariacie.

Najczęściej wybieraną motywacją było w tym wypadku: kierowanie się wartościami (suma $=36^{2}$ ) oraz znajdowanie przyjemności $\mathrm{w}$ takiej posłudze (suma $=24)$. Na trzecim miejscu znajduje się zaś pragnienie podzielenia się dobrem, które samemu się otrzymało od Boga (suma =20). Warto też zauważyć, że kierowanie się wartościami i znajdowanie przyjemności w takiej posłudze to również motywy, które zostały wybrane przez większość osób badanych $(\bmod =1)$. Nie było też motywacji, która nie byłaby przez kogoś wybrana ( $\min =0$, $\max =1$ w każdym wypadku).

Również obecnie wolontariuszy motywują najczęściej: kierowanie się wartościami (suma = 39), przyjemność z takiej pracy $($ suma = 25) oraz pragnienie podzielenia się dobrem, które się samemu otrzymało od Boga (suma = 21). Również $\mathrm{w}$ tym wypadku większość spośród badanych wybrało jako motywy kierowanie się wartościami oraz pragnienie podzielenia się dobrem otrzymanym od Boga $(\bmod =1)$. Każdy z motywów był przez kogoś z grupy wybrany. Jednak, aby zobaczyć, czy istnieje różnica w wybieraniu motywów, które pojawiały się na początku posługi i tych, które kierują wolontariuszami teraz,

2 Sumę tworzy liczba wyborów danej motywacji przez badanych. 
zastosowano test kolejności par Wilcoxa, który jest testem nieparametrycznym badającym istotność różnicy między zmiennymi zależnymi. Aby test ten miał moc 0,90, wystarczy liczność próby badawczej równa 15 osób, dlatego też można go przeprowadzić na próbie 46 osób.

Pierwszą różnicę istotną statystycznie można zaobserwować w motywacji, która określona jest jako: pójście za czyjąś radą w kwestii wyboru wolontariatu ( $\mathrm{p}=0,027 ; Z=2,201)$. Osiem osób pierwotnie $\mathrm{z}$ tego powodu rozpoczęło wolontariat w hospicjum. Tylko dwie osoby uważają, że $\mathrm{z}$ tego powodu dalej trwają w wolontariacie. Czyli tylko u dwóch osób ten motyw jest nadal znaczący. Kolejna motywacja, w występowaniu której widać różnicę istotną statystycznie między sytuacją na początku oraz sytuacją obecną to motywacja określona jako: spotkanie $\mathrm{z}$ problemem choroby nowotworowej u najbliższych ( $\mathrm{p}=0,027 ; Z=2,201)$. Piętnaście osób podaje, że ta motywacja była dla nich ważna, gdy rozpoczynali posługę w hospicjum. Dla dziewięciu osób jest to nadal ważna motywacja. Różnica istotna statystycznie pojawia się również $\mathrm{w}$ podawaniu innych motywacji związanych bardziej z osobistym przeżywaniem ( $\mathrm{p}=0,024$; $Z=2,242$ ). Rozpoczynając posługę, aż dziewięć osób miało inne motywy niż te wymienione, bardziej związane z osobistymi przeżyciami. Teraz jest tylko jedna taka osoba. Podsumowując, można stwierdzić, że w mniejszym stopniu motywacja wolontariuszy do trwania w wolontariacie jest związana $z$ wpływem na nich osób z zewnątrz czy też sytuacji zewnętrznej. Być może te motywy stają się bardziej wewnętrzne w miarę trwania $\mathrm{w}$ wolontariacie.

\section{Zależność między motywacją wolontariuszy oraz ich wiekiem i długościq posługi}

Aby zbadać związek pomiędzy wiekiem i motywacją wolontariuszy, przeprowadzono test rho-Spearmana. Test ten ma moc 0,80 dla liczności próby badawczej równej 45 osób.

Istotna korelacja $(\mathrm{p}<0,05)$ pojawiła się w przypadku motywacji na początku posługi: pragnienie zdobycia nowych umiejętności (rho $=-0,294)$ oraz $\mathrm{w}$ przypadku motywacji obecnej: pragnienie naprawienia swoich błędów w opiece nad bliskimi (rho = 0,325), pragnienie zdobycia nowych umiejętności (rho $=-0,444$ ), naśladowanie 
znajomych (rho $=0,293$ ) oraz spotkanie $\mathrm{z}$ problemem choroby nowotworowej u najbliższych (rho = 0,301). Można zauważyć, że im osoba starsza, tym mniejsza motywacja pragnienia zdobycia nowych umiejętności, zarówno na początku posługiwania, jak i teraz. Im osoba starsza, tym większe znaczenie mają: pragnienie naprawienia błędów z przeszłości, naśladowanie znajomych oraz spotkanie z problemem choroby nowotworowej u najbliższych.

Związek pomiędzy motywacją i długością posługiwania zbadano również za pomocą testu rho-Spearmana. Pojawiła się tylko jedna istotna korelacja $(\mathrm{p}<0,05)$. Wystąpiła ona pomiędzy brakiem motywacji obecnie a długością posługi (rho = -0,369). Im dłużej osoba posługuje w hospicjum, tym rzadziej zdarza się, by nie miała sprecyzowanych motywacji. Jest to zgodne $z$ tym, że osoby niemające sprecyzowanej motywacji raczej szybko odchodzą $z$ wolontariatu hospicyjnego.

\section{Zależność między motywaciq wolontariuszy a rodzajem zaangażowania w wolontariat}

Ponieważ wśród wolontariuszy zbyt mała liczba osób podejmuje posługę w innych rodzajach wolontariatu niż wolontariat stacjonarny, dlatego test rho-Spearmana zastosowano jedynie wobec grupy osób podejmujących wolontariat $\mathrm{w}$ hospicjum stacjonarnym. Osób tych było 40 . Zastosowany test miał moc 0,70 .

Korelacja pomiędzy motywacją wolontariuszy oraz rodzajem podejmowanej przez nich posługi została obliczona za pomocą testu rho-Spearmana. Pojawiło się kilka zależności istotnych statystycznie. Podejmowanie posługi w hospicjum stacjonarnym jest skorelowane $\mathrm{w}$ stopniu istotnym statystycznie $(\mathrm{p}<0,05) \mathrm{z}$ takimi motywacjami na początku posługiwania jak: samotność $($ rho $=-0,425)$, szukanie życzliwego środowiska $($ rho $=-0,459)$, próba radzenia sobie ze swoimi problemami $($ rho $=-0,330)$ oraz z teraźniejszą motywacją spotkania $z$ chorobą nowotworową u najbliższych ( $r$ ho $=-0,297$ ). We wszystkich wypadkach u osób podejmujących tę posługę wymienione motywacje były słabsze niż u tych, którzy jej nie podejmują. 


\section{Dyskusja wyników i wnioski końcowe}

Wśród motywacji badanych w grupach zaangażowanych we wszystkie wolontariaty w Polsce jako najczęstsze są wymieniane motywy: przyjemność (43\%), oczekiwanie, że ktoś mi pomoże, jeśli ja jemu pomogę (32\%) oraz wartości (29\%) (Przewłocka 2010). Mirosław Górecki badając wolontariuszy hospicyjnych podaje jako najczęstszy motyw posługi motywację altruistyczną (46,3\% wolontariuszy) oraz zadaniową (21,8\% wolontariuszy) (Górecki 2000). Niniejsze badania potwierdziły, że najczęstszą motywacją zaangażowania w wolontariat hospicyjny są (zarówno na początku posługi, jak i później): uznawane wartości, następnie znajdywanie przyjemności w tej posłudze oraz pragnienie podzielenia się dobrem otrzymanym od Boga.

Badania zastane wykazały, że motywacja wewnętrzna związana z wartościami, zrozumieniem posługi oraz doświadczaniem wsparcia otrzymywanego od innych jest lepszym predyktorem pozostania w wolontariacie hospicyjnym (Finkelstein 2008). Niniejsze badania to potwierdzają. W stopniu istotnym statystycznie zmniejszają się motywacje związane $\mathrm{z}$ wpływem osób trzecich oraz osobiste i te związane z szukaniem pomocy dla osób najbliższych chorych na nowotwory. Badania niniejsze wykazały też, że istnieją korelacje pomiędzy posługą $\mathrm{w}$ hospicjum stacjonarnym i motywacjami wolontariuszy. Pojawiają się korelacje dodatnie $\mathrm{z}$ takimi motywacjami jak: samotność, szukanie życzliwego środowiska, radzenie sobie z chorobą nowotworową u najbliższych.

Badania zastane wskazują, że osoby młodsze są bardziej nastawione $\mathrm{w}$ swoich motywach na budowanie nowych relacji (Omoto, Snyder, Martino 2000). Osoby zaś starsze są bardzie nastawione altruistycznie na służenie innym. Na zaangażowanie w wolontariat bardzo mocno wpływają indywidualne zasoby badanych związane z ich relacjami osobowymi (Principi, Naegele, Di Rosa, Lamura 2016). Motywacjami dla takich wolontariuszy są generatywność związana z chęcią niesienia pomocy następnym pokoleniom oraz rozwój osobisty i dobre samopoczucie (Yamashita, López, Soligo, Keene 2017). Badania niniejsze częściowo to potwierdziły. Im dłuższe posługiwanie i dłuższy staż, tym motywacja staje się bardziej konkretna. U osób starszych posługujących w hospicjum, niezależnie od 
ich stażu, mniejsze znaczenie mają motywacje poznawcze: zdobywanie nowych umiejętności czy też wiedzy. Większe zaś jest pragnienie naprawienia błędów z przeszłości, naśladowanie znajomych oraz doświadczenie choroby nowotworowej u najbliższych.

Badania przeprowadzone wśród wolontariuszy hospicyjnych pokazują, dlaczego osoby te przychodzą do hospicjum, ale również dlaczego w nim zostają. W miarę upływu czasu ich motywacja staje się bardziej konkretna. Odchodzą natomiast te osoby, które nie do końca wiedzą, czego szukają. Aby zostać w posłudze, wolontariusze budują motywację bardziej wewnętrzną, zmniejsza się znaczenie motywacji zewnętrznej, związanej z potrzebami chwili czy też z nakłanianiem do wolontariatu przez innych. Starsze osoby rzadziej zostają w wolontariacie ze względu na pragnienie zdobywania nowych umiejętności. Jednak większość tych, którzy przychodzą pełnić posługę w wolontariacie hospicyjnym, widzi w hospicjum szczególne środowisko, poszukuje w nim życzliwości i przezwyciężenia samotności. To potwierdza, że od początku istnienia hospicja stawały się domami zarówno dla chorych i umierających, jak również dla ich opiekunów.

Wyniki przeprowadzonych badań mogą być pomocne w rekrutowaniu nowych wolontariuszy. Badanie ich motywacji pozwala w pewnym stopniu przewidzieć na ile będą oni wytrwali w posługiwaniu. Osoby niemające sprecyzowanych motywów rzadko zostają w wolontariacie na dłużej. Jednak są i takie, które pod wpływem wolontariatu się zmieniają i dojrzewają, o czym trzeba również pamiętać decydując o przyjęciu lub odrzuceniu kandydata.

Podstawowym ograniczeniem przeprowadzonych badań był fakt, że badani podawali swoją motywację z przeszłości i obecną. Dane te nie są więc równoznaczne. Wartościowe byłoby więc na przyszłość przeprowadzenie badań longitudinalnych, pozwalających na przestrzeni lat porównać ich motywacje. 


\section{Bibliografia}

Andersson B., Ohlen J. (2005). Being a hospice volunteer, „Palliative Medicine”, t. 19, nr 8, s. 602-609. DOI: 10.1191/0269216305pm1083oa.

Babbie E. (2013). Podstawy badań spotecznych, przeł. M. Mozga-Górecka, Warszawa: Wydawnictwo Naukowe PWN.

Bacter C., Marc C. (2016). Student's involvement in social volunteering, „Bulletin of the Transilvania University of Braşov", t. 9, nr 1, s. 81-89.

Basińska A., Nowak M. (2010). Motywowanie i motywacja do pracy wolontariuszy, Poznań: WOLIMP.

Campbell R., Warner A. (2016). Connecting the Characteristics of International Volunteer Experiences with Their Impacts: A Canadian Case Study, „Voluntas”, t. 27, nr 2, s. 549-573. DOI: 10.1007/s11266-015-9550-x.

Chien H.M. (2017). A study of volunteers' science service satisfaction in relation to their self-directed learning and motivation, "Journal of Baltic Science Education", t. 16, nr 2, s. 188-198.

Dutkiewicz E. (1997). Opieka duchowa nad umierajacym, [w:] M.D. Śpiewakowska, R. Szpakowski (red.), Przed przejsciem. Rozważania o opiece hospicyjnej, Warszawa: Wydawnictwo Salezjańskie, s. 105-114.

Erasmus B., Morey P.J. (2016). Faith-Based Motivations: Exploring the Applicability of the Volunteer Functions Inventory to the Motivations and Satisfactions Levels of Volunteers in an Australian Faith-Based Organization, „Voluntas", t. 27, nr 3, s. 1343-1360. DOI: 10.1007/s11266-016-9717-0.

Finkelstein M.A. (2008). Volunteer satisfaction and volunteer action: a functional approach, „Social Behavior and Personality”, t. 36, nr 1, s. 9-18, https://doi.org/10.2224/sbp.2008.36.1.9.

Gasiul H. (2002). Teorie emocji i motywacji. Rozważania psychologiczne, Warszawa: Wydawnictwo UKSW.

Goodman S., Tredway G. (2016). Antecedents of perceived graduate employability: A study of student volunteers in a community-based organisation, „SA Journal of Industrial Psychology", t. 42, nr 1, a1315. DOI: 10.4102/sajip. v42i1.1315.

Górecki M. (2000). Hospicjum w stużbie umierajacych, Warszawa: Wydawnictwo Akademickie „Żak”.

Gumkowska M. (2005). Wolontariat, filantropia i 1\%. Raport z badań 2005, Warszawa: Stowarzyszenie Klon-Jawor.

Jackson L., Adarlo G. (2016). Bridging Cultures Through Unpaid Labor: US Volunteer Teachers' Experiences in China's Yunnan Province, „Voluntas”, t. 27, nr 5, s. 2330-2352. DOI: 10.1007/s11266-014-9519-1.

Kapuścińska M. (2012). Motywy podejmowania dziatań wolontariackich wśród mtodzieży szkolnej, [w:] T. Zbyrad, B. Krempa (red.), Pomoc jako zachowanie prospoteczne, Lublin: Wydawnictwo KUL, s. 317-326.

Krakowiak P., Janowicz A. (2008). Historia $i$ wspótczesność wolontariatu hospicyjnego, [w:] P. Krakowiak, A. Modlińska, J. Binnebesel (red.), 
Podręcznik koordynatora wolontariatu hospicyjnego, Gdańsk: Biblioteka Fundacji Hospicyjnej, s. 1-24.

Kumnig M., Schnitzer M., Beck T.N., Mitmansgruber H., Jowsey S.G., Kopp M., Rumpdol G. (2015). Approach and Avoidance Motivations Predict Psychological Well-Being and Affectivity of Volunteers at the Innsbruck 2008 Winter Special Olympics, „Voluntas”, t. 26, nr 3, s. 801-822. DOI: 10.1007/s11266-014-9462-1.

Kwakye J.N., Garner M., Baldwin D.S., Bamford S., Pinkney V., Bishop F.L. (2016). Altruism personal benefit, and anxieties: a phenomenological study of healthy volunteers' experiences in a placebo-controlled trial of duloxetine, „Human Psychopharmacology: Clinical and Experimental”, t. 31, nr 4, s. 332-340. DOI: 10.1002/hup.2543.

Li C., Wu Y. Kee Y.H. (2016). Validation of the Volunteer Motivation Scale and its relations with work climate and intention among Chinese volunteers, „Asian Journal of Social Psychology”, t. 19, nr 2, s. 124-133, https://doi. org/10.1111/ajsp.12127.

Nencini A., Romaidi D., Maneghini A.M. (2016). Volunteer Motivation and Organizational Climate: Factors that Promote Satisfaction and Sustained Volunteerism in NPOs, „Voluntas”, t. 27, nr 2, s. 618-639. DOI: 10.1007/ s11266-015-9593-z.

Omoto A.M., Snyder M., Martino S.C. (2000). Volunteerism and the Life Course: Investigating Age-Related Agendas for Action, „Basic and Applied Social Psychology", t. 22, nr 3, s. 181-197, https://doi.org/10.1207/ S15324834BASP2203_6.

Ożóg K. (2012). Dziatalność w wolontariacie - między stużba drugiemu cztowiekowi a pseudoaltruizmem, [w:]: T. Zbyrad, B. Krempa (red.), Pomoc jako zachowanie prospoteczne, Lublin: Wydawnictwo KUL, s. 327-340.

Principi A.S., Naegele G., Di Rosa M., Lamura G. (2016). Understanding the link between older volunteers' resources and motivation to volunteer, „Educational Gerontology”, t. 42, nr 2, s. 144-158. DOI: 10.1080/03601277.2015.1083391.

Przewłocka J. (2010). Zaangażowanie spoteczne Polaków w roku 2010: Wolontariat, flantropia, 1\%. Raport z badań, Warszawa: Stowarzyszenie Klon-Jawor.

Ramos R., Gunter S., Brauchli R., Bauer G., Wehnar T., Hammig O. (2016). Exploring the Interaction between Volunteering Status, Paid Job Characteristics and Quality of Volunteers' Motivation on Mental Health, „Voluntas”, t. 27, nr 2, s. 790-809. DOI: 10.1007/s11266-015-9647-2.

Saunders C. (1980). Hospicjum św. Krzysztofa, [w:] H. Bortnowska (red.), Sens choroby, sens śmierci, sens życia, Kraków: Wydawnictwo Znak, s. 266-296.

Sobolewska-Popko A.M. (2012). Czy pomaganie męczy? Jak skutecznie pomagać nie zatracając siebie?, [w:] T. Zbyrad, B. Krempa (red.), Pomoc jako zachowanie prospoteczne, Lublin: Wydawnictwo KUL, s. 349-358. 
Starnes B.J., Wymer W.W. (1999). Demographics, Personality Traits, Roles, Motivations and Attrition Rates of Hospice Volunteers, "Journal of Nonprofit and Public Sector Marketing", t. 7, nr 2, s. 67-76, https://doi. org/10.1300/J054v07n02_06

Stukas A.A., Snyder M., Clary E.G. (2016). Understanding and Encouraging Volunteerism and community involvement, „The Journal of Social Psychology", t. 156, nr 3, s. 243-255. DOI: 10.1080/00224545.2016.1153328.

Ustawa o dziatalności pożytku publicznego i wolontariacie. (2003). Dz.U. 2003, nr 96, poz. 873 z późniejszymi poprawkami.

Van Schie S., Gunter S.T., Oostlander J., Wehner T. (2015). How the Organizational Context Impacts Volunteers: A Differentiated Perspective on Self-determined Motivation, „Voluntas”, t. 26, nr 4, s. 1570-1590. DOI: 10.1007/s11266-014-9472-z.

Weber T. (2009). Oswajanie umierania. Ocena terapii paliatywnej w opiece domowej, w hospicjum i w szpitalu, Kraków: Wydawnictwo Fall.

Winterich K.P., Aquino K., Mittal V., Swartz R. (2013). When Moral Identity Symbolization Motivates Prosocial Behavior: The Role of Recognition and Moral Identity Internalization, „Journal of Applied Psychology”, t. 98, nr 5, s. 759-770, https://ssrn.com/abstract=2261193.

Włodarczyk E. (2011). Odcienie $i$ cienie wolontariatu, „Kultura i Edukacja”, t. 82, nr 3, s. 26-50, <https://repozytorium.amu.edu.pl/bitstream/ 10593/12543/1/E.\%20Wlodarczyk\%2C\%20Odcienie\%20i\%20cienie \%20wolontariatu\%2C\%20Kultura\%20i\%20Edukacja.indd.pdf> [dostęp: 30:04.2019].

Wu Y., Li C., Khoo S. (2016). Predicting Future Volunteering Intentions Through a Self-determination. Theory. Perspective, „Voluntas”, t. 27, nr 3, s. 1266-1279. DOI: $10.1007 / \mathrm{s} 11266-015-9570-6$.

Yamashita T., López E.B., Soligo M., Keene J.R. (2017). Older Lifelong Learners Motivations for Participating in Formal Volunteer Activities in Urban Communities, „Adult Education Quarterly”, t. 67, nr 2, s. 118-135. DOI: $10.1177 / 0741713616688957$.

\section{ADRES DO KORESPONDENCJI}

Dr Anna Seredyńska

Akademia Ignatianum w Krakowie

Wydział Pedagogiczny

e-mail: anna.seredynska@ignatianum.edu.pl 